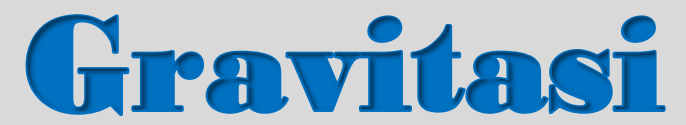

\title{
Analisa Kualitas Klorofil dan Absorbansi Daun Jarak Merah (Jatropha Gossypifolia L.) dan Daun Biduri (Calotropis Gigantea) Sebagai Bahan Pewarna Pada Dye Sensitized Solar Cell (DSSC)
}

(Analysis of Chlorophyll Quality and Absorbance of Red Jatropha (Jatropha Gossypifolia L.) Leaves and Biduri Leaves (Calotropis Gigantea) as Dye Sensitized Solar Cells (DSSC)))

\author{
A. R. Ramadhanty dan Iqbal \\ Fakultas Matematika dan Ilmu Pengetahuan Alam Universitas Tadulako
}

Info

Article history:

Received: 29 December 2021

Accepted: 30 December 2021

Published: 31 December 2021

\begin{abstract}
Abstrak.
Telah dianalisis kualitas klorofil dan absorbansi pada daun jarak merah (Jatropha gossypifolia L.) dan daun biduri (Calotropis gigantean) sebagai bahan pewarna pada Dye Sensitized Solar Cell (DSSC). Penelitian ini bertujuan untuk mengetahui bagaimana pengaruh konsentrasi terhadap nilai absorbansi dan menghitung energi gap larutan ekstra daun biduri dan jarak merah. Hasil penelitian menunjukkan bahwa pada konsentrasi $25 \mathrm{mg} / \mathrm{ml}$ nilai absorbansi paling besar sebesar 2,242 a.u untuk klorofil dan 2,312 a.u untuk antosianin, sedangkan pada konsentrasi $10 \mathrm{mg} / \mathrm{ml}$ nilai absorbansi paling rendah sebesar 0,953 a.u untuk klorofil dan 0,868 a.u untuk antosianin. Hasil pengolahan data diperoleh nilai energi gap pada daun jarak merah dan daun biduri berturut-turut sebesar 1,89 eV dan 2,80 eV. Berdasarkan hasil tersebut dapat diketahui bahwa daun jarak merah dan daun biduridapat digunakan sebagai bahan pewarna pada DSSC karena energi gap kurang dari $4 \mathrm{eV}$.
\end{abstract}

Abstract.

The quality of chlorophyll and absorbance in red jatropha (Jatropha gossypifolia L.) and biduri (Calotropis gigantean) leaves have been analyzed as a dye in Dye Sensitized Solar Cell (DSSC). This study aims to determine how the effect of concentration on the absorbance value and calculate the energy gap of biduri leaf extra solution and red distance. The results showed that at a concentration of $25 \mathrm{mg} / \mathrm{ml}$ the highest absorbance value was 2.242 a.u for chlorophyll and 2.312 a.u for anthocyanins, while at a concentration of $10 \mathrm{mg} / \mathrm{ml}$ the lowest absorbance value was 0.953 a.u for chlorophyll and 0.868 a.u for anthocyanins. The results of data processing obtained the value of the energy gap in red jatropha leaves and biduri leaves respectively $1.89 \mathrm{eV}$ and $2.80 \mathrm{eV}$. Based on these results, it can be seen that red jatropha leaves and biduri leaves can be used as coloring agents in DSSC.) because the energy gap is $<4 \mathrm{eV}$.

\section{Kata kunci: \\ Antosianin \\ Absorbani \\ Klorofil \\ Keywords: \\ Anthocyanin \\ Absorbance \\ Energy Gap \\ Chlorophyll}

*) e-mail: Adindarezkiramadhanty24@gmail.com

DOI: $10.22487 /$ gravitasi.v20i2.15734

\section{PENDAHULUAN}

Ketersediaan energi di dunia saat ini menjadi salah satu tantangan besar bagi pemenuhan kebutuhan energi masa depan. Energi memiliki peranan yang sangat penting dalam segala aspek kehidupan. Namun kebutuhan ketersediaan energi yang terus meningkat memperngaruhi persediaan sumber energi fosil, yang selama ini menjadi salah satu sumber energi utama. Biasanya energi ini diperoleh dari minyak, gas bumi dan berbagai macam sumber energi fosil lainnya. Eksplorasi sumber energi fosil yang tidak terencana dapat mengakibatkan pengikisan dari alam yang nantinya menyebabkan kerusakan alam dan terjadinya pemanasan global sehingga berdampak pada kehidupan manusia itu sendiri.

Energi terbarukan merupakan energi yang tidak dapat habis, sehingga dimanfaatkan secara terus menerus. Beberapa contoh energi terbarukan yang dapat dimanfaatkan saat ini adalah energi tenaga angin, tenaga air dan energi matahari. Salah satu energi yang paling potensial untuk dimanfaatkan 
sebagai energi terbarukan adalah energi matahari. Posisi letak geografis Indonesia yang berada di bawah garis khatulistiwa menciptakan iklim tropis yang memungkinkan untuk pemanfaatan energi matahari sepanjang tahun [1].

Kelemahan yang dimiliki sel surya berbasis silikon mendorong para peneliti mempertimbangkan untuk mengembangkan jenis sel surya terbarukan yaitu Dye Sensitive Solar Cell (DSSC) [1-6]. DSSC merupakan salah satu solusi potensial untuk generasi kedepan sel surya jenis ini memiliki beberapa keunggulan jika dibandingkan dengan sel surya sebelumnya yaitu sel surya berbasis silikon. Salah satu kelebihannya yaitu biaya produksinya yang lebih murah dan relatif rendah [7]. Namun kelemahan dari sel surya jenis ini adalah nilai efesiensi yang rendah. Hal ini disebabkan karena sensitifitas zat warna yang digunakan [8].

Tumbuhan Jarak Merah dan bunga Roviga sangat banyak terdapat di Sulawesi Tengah khususnya di Kota Palu. Tumbuhan ini sangat banyak dijumpai dimana mana dan pemanfaatannya masih kurang. Penelitian ini mempelajari potensi pigmen klorofil dari bahan bunga Roviga (Calotropis gigantea) $[9,10]$ dan karakterisasi serapan cahaya dari daun Jarak Merah (Jatropha gossypifolia L.) [11]. Berdasarkan hal ini perlu adanya kajian tentang kualitas klorofil dari bunga Biduri (Calotropis gigantean) mengenai absorbansi, energi gap sebagai pengembangan DSSC dan karakterisaasi serapan cahaya dari daun Jarak Merah (Jatropha gossypifolia L.) melalui analisa spektroskopsi UV-vis.

Antosianin dan klorofil dapat digunakan sebagai zat pewarna pada DSSC karena dapat menyerap energi matahari pada panjang gelombang sekitar $500 \mathrm{~nm}$ untuk antosianin dan sekitar $300 \mathrm{~nm}$ dan $600 \mathrm{~nm}$ untuk klorofil. Semakin banyak energi matahari yang diserap oleh zat pewarna maka semakin tinggi efisiensi yang dihasilkan DSSC [12]. Dengan demikian, berdasarkan kajian terdahulu maka diharapkan penelitian ini dapat menganalisis kaitan antara pengaruh konsentrasi klorofil terhadap nilai absorbansi dan zat pewarna antosianin. Selanjutnya dari hasil ini, diharapkan terjadi peningkatan energi matahari yang dapat diserap, sehingga efisiensi DSSC dapat semakin tinggi.

\section{BAHAN DAN METODE}

Alat dan bahan yang digunakan pada penelitian ini adalah:

1. Gunting, digunakan untuk memotong daun jarak merah dan daun biduri.

2. Timbangan digital, digunakan untuk menimbang daun jarak merah dan daun biduri yang di ekstrak

3. Blender, digunakan untuk menghaluskan daun jarak merah dan daun biduri.

4. Gelas ukur, digunakan untuk mengukur jumlah zat yang digunakan.

5. Gelas erlemeyer, digunakan sebagai wadah larutan.

6. Batang pengaduk, digunakan untuk mengaduk saat mencampurkan bahan.

7. Gelas Beker, sebagai wadah untuk penyimpanan dan pencampuran.

8. Aluminium foil, digunakan untuk menutup gelas erlemeyer pada proses ekstraksi bahan.

9. Kertas saring, digunakan untuk menyaring larutan.

10. Mortal dan pastle, digunakan untuk menghaluskan daun jarak merah dan daun biduri.

11. Corong, digunakan untuk memindahkan larutan dari 1 wadah ke wadah yang lain.
12. Spektrofotometri UV-vis, digunakan untuk proses pengukuran absorbansi larutan.

Penelitian ini yang terdiri dari beberapa tahapan yang sebagai berikut:

1. Tahap Persiapan

Tahap persiapan ini dimulai dengan melakukan studi literatur. Studi literatur ini dilakukan dengan cara mencari materi-materi di berbagai sumber seperti buku, internet dan sumber informasi lainnya.

\section{Tahap Pengeringan Bahan}

Tahap pengeringan bahan daun Jarak merah dan daun biduri menggunakan oven dengan suhu $400 \mathrm{C}$ dalam jangka waktu 3 hari. Setelah dikeringkan kemudian dihaluskan menggunakan blender. Setelah bahan keduanya dihaluskan kemudian di timbang berat keseluruhan dan ditimbang per 1gram tiap sampel.

\section{Tahap Ekstraksi}

Tahap ini dimulai dari menyiapkan pelarut Etanol $96 \%$ dan Etanol 96\%+ HCL 1\%. Kemudian sampel daun jarak merah dan daun biduri dipisahkan menjadi 7 konsentrasi yaitu 25 $\mathrm{mg} / \mathrm{ml}, 20 \mathrm{mg} / \mathrm{ml}, 16 \mathrm{mg} / \mathrm{ml}, 14 \mathrm{mg} / \mathrm{ml}, 12 \mathrm{mg} / \mathrm{ml}, 11 \mathrm{mg} / \mathrm{ml}$ dan $10 \mathrm{mg} / \mathrm{ml}$ pada tiap sampel, total sampel keduabahan yaitu 14 sampel. Sampel daun jarak merah menggunakan pelarut Etano196\% + HCL 1\% dan sampel daun Biduri menggunakan pelarut Etanol 96\% murni tanpa campuran ditutup menggunakan alumunium foil ditempatkan dalam ruang gelap selama 1x24 jam. Setelah dimasirasi selama 24 jam, larutan kemudian disaring menggunakan kertas saring.

4. Tahap Pengukuran Nilai Absorbansi

Bahan yang telah selesai di masirasi dan disaring kemudian dibawa ke Laboratorium Kimia untuk di uji menggunakan UV-Vis. Larutan kemudian dimasukkan kedalam kuvet yang sudah dibersihkan kemudian diukur nilai absorbansi untuk setiap konsentrasi menggunakan UV-Vis pada anjang gelombang 400-700 nm.

\section{Tahap Perhitungan Energi Gap}

Perhitungan energi gap dilakukan dengan menggunakan data Panjang gelombang dari nilai dari tiap-tiap konsentrasi dengan menggunakan Spektrofotometer UV-Vis.

\section{HASIL DAN PEMBAHASAN}

Gambar 1 menunjukkan grafik spektrum absorbansi Jarak Merah dengan konsentrasi berbeda-beda, $10 \mathrm{mg} / \mathrm{ml}, 11 \mathrm{mg} / \mathrm{ml}$, $12 \mathrm{mg} / \mathrm{ml}, 14 \mathrm{mg} / \mathrm{ml}, 16 \mathrm{mg} / \mathrm{ml}, 20 \mathrm{mg} / \mathrm{ml}$ dan $25 \mathrm{mg} / \mathrm{ml}$ sebagai fungsi panjang gelombang.

Daun jarak merah memiliki warna merah keunguan yang disebabkan kandungan antosianin. Dari Gambar 4.1, grafik antosianin $25 \mathrm{mg} / \mathrm{ml}, 20 \mathrm{mg} / \mathrm{ml}, 16 \mathrm{mg} / \mathrm{ml}, 14 \mathrm{mg} / \mathrm{ml}, 12$ $\mathrm{mg} / \mathrm{ml}, 11 \mathrm{mg} / \mathrm{ml}$ dan $10 \mathrm{mg} / \mathrm{ml}$, menunjukkan bahwa zat warna dari ekstrak daun jarak merah dapat menyerap cahaya dalam rentang panjang gelombang antara $420 \mathrm{~nm}$ sampai 700 $\mathrm{nm}$. Hasil pengamatan daun jarak merah25 $\mathrm{mg} / \mathrm{ml}$ pada panjang gelombang $434 \mathrm{~nm}$ dan $654 \mathrm{~nm}$ masih mengandung klorofil a, untuk antosianin sendiri beradapada panjang gelombang $532 \mathrm{~nm}$. Begitupun pada grafik daun jarak merah $20 \mathrm{mg} / \mathrm{ml}, 16 \mathrm{mg} / \mathrm{ml}$, dan $14 \mathrm{mg} / \mathrm{ml}$ masih mendominasi panjang gelombang $600 \mathrm{~nm}-654 \mathrm{~nm}$ untuk klorofil a, untuk antosianinnya berada pada panjang gelombang yang masih dalam kategori baik 111025 mg/ml 20 mg/ml 16 mg/ml 14 $\mathrm{mg} / \mathrm{ml} 12 \mathrm{mg} / \mathrm{ml} 11 \mathrm{mg} / \mathrm{ml} 10 \mathrm{mg} / \mathrm{ml} 430480530580630$ 
680 Panjang gelombang (nm) Absorbansi 21 yaitu $532 \mathrm{~nm}$. Pada grafik daun jarak merah $12 \mathrm{mg} / \mathrm{ml}$ klorofil a terbaca pada panjang gelombang $440 \mathrm{~nm}$ dan $649 \mathrm{~nm}$, sedangkan untuk antosianinnya juga terbaca pada $529 \mathrm{~nm}$ dan $532 \mathrm{~nm}$ dengan nilai absorbansi yang sangat tinggi yaitu 3,165 a.u. Kemudian untuk grafik daun Jarak Merah $11 \mathrm{mg} / \mathrm{ml}$ dan $10 \mathrm{mg} / \mathrm{ml}$ spektrum antosianinnya berada pada range panjang gelombang $532 \mathrm{~nm}$ dan untuk spectrum klorofilnya masih tinggi dengan range panjang gelombang $654 \mathrm{~nm}$ dengan nilai absorbansi 1,528 a.u dan 1,290 a.u. Jadi semakin rendah konsentrasi larutannya maka semakin tinggi spektrum antosianin dan klorofil yang terdapat pada daun jarak merah, diketahui pada daun jarak merah tidak hanya terkandung antosianin tapi juga ada kandungan klorofil yang justru lebih dominan.

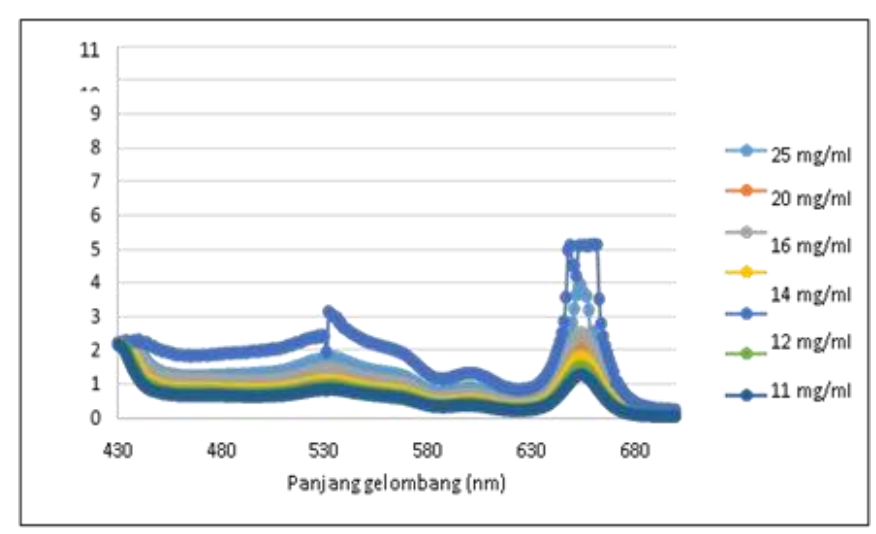

Gambar 1. Grafik spektrum absorbansi jarak merah tiap konsentrasi larutan

Gambar 2 menunjukkan grafik spektrum absorbansi untuk Daun Biduri. Konsentrasi larutan dengan bahan daun Biduri juga dibuat berbeda-beda yaitu $10 \mathrm{mg} / \mathrm{ml}, 11 \mathrm{mg} / \mathrm{ml}, 12$ $\mathrm{mg} / \mathrm{ml}, 14 \mathrm{mg} / \mathrm{ml}, 16 \mathrm{mg} / \mathrm{ml}, 20 \mathrm{mg} / \mathrm{ml}$ dan $25 \mathrm{mg} / \mathrm{ml}$ sebagai fungsi panjang gelombang.

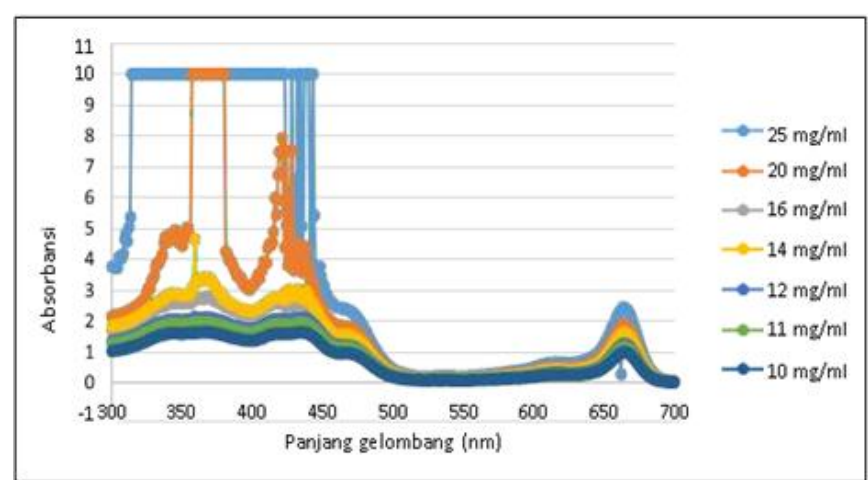

Gambar 2. Grafik Spektrum Absorbansi Daun Biduri Tiap Konsentrasi Larutan

Pada hasil pengukuran grafik daun biduri $25 \mathrm{mg} / \mathrm{ml}$ panjang gelombang $443 \mathrm{~nm}, 447 \mathrm{~nm}$ dan $664 \mathrm{~nm}$ mengandung klorofil a yang memiliki nilai absorbansi yang $11 \quad 10-1300$ 350400450500550600650700 Panjang gelombang (nm) $25 \mathrm{mg} / \mathrm{ml} 20 \mathrm{mg} / \mathrm{ml} 16 \mathrm{mg} / \mathrm{ml} 14 \mathrm{mg} / \mathrm{ml} 12 \mathrm{mg} / \mathrm{ml} 11 \mathrm{mg} / \mathrm{ml}$ $10 \mathrm{mg} / \mathrm{ml}$ Absorbansi 22 paling maksimum yaitu 3,378 a.u. Pada grafik daun biduri $20 \mathrm{mg} / \mathrm{ml}$ panjang gelombang $421 \mathrm{~nm}$, $424 \mathrm{~nm}$, dan $428 \mathrm{~nm}$ memiliki nilai absorbansi yang paling tinggi yaitu 7,911 a.u , untuk range panjang gelombang paling baik berada pada panjang gelombang $664 \mathrm{~nm}$ dengan nilai absorbansi 1,840 a.u. Pada grafik selanjutnya yaitu $16 \mathrm{mg} / \mathrm{ml}$ panjang gelombangnya terbaca pada $367 \mathrm{~nm}, 417 \mathrm{~nm}, 433 \mathrm{~nm}$, dan $664 \mathrm{~nm}$. Untuk panjang gelombang $433 \mathrm{~nm}$ memiliki nilai absorbansi paling tinggi yaitu 2,583 a.u. Kemudian untuk grafik daun biduri $14 \mathrm{mg} / \mathrm{ml}$ terdapat lima puncak gelombang yang memiliki nilai $363 \mathrm{~nm}, 367 \mathrm{~nm}, 432 \mathrm{~nm}, 438 \mathrm{~nm}$ dan 664 nm dengan nilai absorbansi paling tinggi berada di range panjang gelombang $432 \mathrm{~nm}$ yaitu 2,999 a.u. Pada grafik 12 $\mathrm{mg} / \mathrm{ml}$ puncak gelombang yang terbaca dari $359 \mathrm{~nm}, 434 \mathrm{~nm}$ dan $664 \mathrm{~nm}$ dari ketiga puncak ini yang paling maksimum yaitu di nilai $359 \mathrm{~nm}$ akan tetapi nilai ini tidak mencapai angka minimum pada spectrum klorofil, jadi pada panjang gelombang $434 \mathrm{~nm}$ dengan nilai absorbansi 2,091 a.u yang paling baik. Terakhir pada grafik daun biduri $11 \mathrm{mg} / \mathrm{ml}$ dan 10 $\mathrm{mg} / \mathrm{ml}$ memiliki niai panjang gelombang yangsama yaitu 434 $\mathrm{nm}$ dengan nilai absorbansi 1,603 a.u yang bearti nilai minimum spectrum klorofil a. Jadi pada daun biduri kandungan spektrum klorofilnya bisa dikatakan baik dan semakin rendah konsentrasi larutannya kandungan spectrum klorofilnya semakin tinggi.

Besar energi gap dapat dihitung menggunakan rumus energi foton dimana $\lambda$ merupakan panjang gelombang yang memiliki nilai absorbansitertinggi. Dari hasil perhitungan energi gap yang diperoleh larutan daun biduri yang memiliki nilai paling rendah berada pada tiap konsentrasi dengan panjang gelombang $664 \mathrm{~nm}$ yaitu $1,86 \mathrm{eV}$, sedangkan larutan daun biduri yang memiliki nilai paling tinggi berada pada konsentrasi $50 \mathrm{mg} / \mathrm{ml}$ dengan panjang gelombang $443 \mathrm{~nm}$ yaitu 2,80 eV. Kemudian perhitungan energi gap yang diperoleh larutan daun jarak merah yang memiliki nilai paling rendah berada pada tiap konsentrasi dengan panjang gelombang $654 \mathrm{~nm}$ yaitu $1,89 \mathrm{eV}$ dan untuk nilai paling tinggi berada pada 23 konsentrasi dengan panjang gelombang 530 $\mathrm{nm}$ yaitu 2,34 eV. Dari hasil perhitungan energi gap menunjukkan bahwa larutan Antosianin dan klorofil memiliki sifat semikonduktor karena memiliki energi gap kurang dari 4 $\mathrm{eV}[5]$.

\section{KESIMPULAN}

Pada pengaruh konsentrasi $25 \mathrm{mg} / \mathrm{ml}$ menunjukkan bahwa nilai terbesar absorbansi berturut-turut sebesar 2,242 a.u untuk klorofil dan 2,312 a.u antosianin, pada konsentrasi $10 \mathrm{mg} / \mathrm{ml}$ diperoleh nilai terendah absorbansi berturut-turut sebesar 0,953 a.u untuk klorofil dan 0,868 a.u untuk antosianin. Hal ini menunjukkan bahwa semakin pekat larutan ekstrak maka semakin besar absorbansinya. Hasil ekstrak daun jarak merah tidak hanya ada kandungan antosianin tapijuga ada kandungan klorofil yang justru lebih dominan. Nilai energi gap pada daun jarak merah dan daun biduri berturut-turut sebesar 1,89 eV dan 2,80 eV. Energi gap 1,89 eV merupakan spektrum klorofil a dan energi gap 2,80 eV merupakan spektrum klorofil b. Berdasarkan hasil tersebut dapat diketahui bahwa daun jarak merah dan daun biduri dapat digunakan sebagai bahan pewarna pada Dye Sensitized Solar Cell (DSSC) dikarenakan energi gap $<4 \mathrm{eV}$.

\section{UCAPAN TERIMA KASIH}

Terimakasih kepada Jurusan Fisika FMIPA UNTAD yang sudah memfasilitasi dalam penyelesaian tugas akhir ini. 


\section{REFERENSI}

[1] Hardeli.Dkk. (2013). Dye Sensetized Solar Sel (DSSC) Berbasis Nanopori TiO2 Menggunakan Antosianin Dari Berbagai Sumber Alami. Jurnal FMIPA UNP, h: 155-156.

[2] Basri. S. A. (2015). Pengawetan Klorofil sebagai zat pewarna untuk bahan DSSC (Dye Sensitized Solar Cell) Dengan menggunakan Freeze Drying. Fisika, Palu: 10,11.

[3] Sumaryanti. U., Agus S., dan Purnama, B. (2011). Karakterisasi Optik dan Listrik Larutan Klorofil Spirulina Sp Sebagai Dye Sensitized Solar Cell. Material dan Energi Indonesia 01, No. 03: $141-147$

[4] Mil, G., Kasman, K., \& Iqbal, I. (2017). Analisa Kualitas Klorofil Daun Jarak Kepyar (Ricinus comunis L) Sebagai Bahan Pewarna Pada Dye Sensitized Solar Cell (DSSC). Gravitasi, 16(2). https://doi.org/10.22487/gravitasi.v16i2.9475

[5] Niska, A., Darwis, D., \& Ulum, S. (2018). Studi Awal Buah Kaktus Pir (Opuntia Ficus Indica) Sebagai Zat Pewarna untuk Bahan Aktif Dye Sensitized Solar Cell (DSSC). Gravitasi, 15(2). https://doi.org/10.22487/gravitasi.v15i2.9428

[6] Kumara, M. S., \& Prajitno, G. (2012). Studi Awal Fabrikasi Dye Sensitized Solar Cell (DSSC) Dengan Menggunakan Ekstraksi Daun Bayam (Amaranthus Hybridus L) Sebagai Dye Sensitizer Dengan Variasi Jarak Sumber Cahaya Pada DSSC. Fisika.
[7] Nadaek, S. M., \& Susanti, D. (2012). Variasi temperatur dan waktu tahan kalsinasi terhadap unjuk kerja semikonduktor $\mathrm{TiO} 2$ sebagai dye sensitized solar cell (DSSC) dengan dye dari ekstrak buah naga merah. Jurnal Teknik ITS, 1(1), F81-F86.

[8] Setiadji Soni, Atthar Luqman Ifansyah, Bio Insan Akbar. "Studi Komputasi Senyawa Dopamin dan Dopamin TI $(\mathrm{OH}) 2$ untuk Aplikasi Sel Surya Tersensitasi Zat Warna". Jurnal Teknologi Technoscientia, Vol. 9, no. 2, h: 205-207. Sudjadi. (1998). Metode Pemisahan. Yogyakarta: Kanisius.

[9] Kumar, G., Karthik, L. dan Rao, K. V. B. (2011). A Review on Pharmacological and Phytochemical Profile of Calotropis gigantea Linn. Pharmacologyonline 1: 1-8.

[10] Nigeria: Eur J Med. Sarkar, S. Chakraverty, R, and Ghosh, A. (2014). Calotropis gigantea Linn, A Complete busket of Indian Traditional Medicine. IJSPR. 2 (1): 7-17.

[11] Oduola, T. (2005). Mechanisme Of Action of Jatropha Gossypifolia Stem Latex As A Haemostatic Agent.

[12] Elsa, A. A., Ramelan, A. H., \& Suharyana (2013). Sintesa Titanium Dioxide (TiO2) Untuk Dye Sensitized Solar Cell Dengan Antosianin Bunga Rosella (Hibicus Sabdariffa). Indonesian Journal Of Applied Physics, Vol 3 No 2, hal 181. Gratzel, Michael.(2003). Dye Sensitized Solar Cell Photochemistry Reviews 4 h: 145- 153. 